УДК: 321.7

https://doi.org/10.34142/24130060.2020.20.1.09

\title{
ПРОБЛЕМАТИКА ДЕМОКРАТИЗАЦІЇ У КОНТЕКСТІ ФОРМУВАННЯ НОВОГО СВІТОВОГО ПОРЯДКУ
}

\author{
I. В. Застава \\ Харківський національний університет імені В.Н. Каразіна
}

Проаналізовано та узагальнено теоретико-методологічних підходів тлумачення та аналізу світового порядку. Розглянуто ключові питання впливу демократизаційних процесів на формування нового світового порядку. Визначено, щзо суть нового світового порядку полягає в побудові єдиного, взаємопов'язаного $і$ глобального світу, відмову від верховенства начіональних держав $i$ пріоритеті загальнолюдських інтересів. Обтрунтовано, щзо для вирішення проблем демократизащії в умовах нового світового порядку, необхідно реалізувати наступні принципи: це неодмінна орієнтація західних демократій на власні фундаментальні цінності: свободу, права людини, толерантність, демократію, верховенство права і сочіальну ринкову економіку; ие визнання необхідності $i$ повагу міжнародного порядку, заснованого на спільних иінностях, на праві, злагоді, співробітництво та участі в управлінні, можливість політичного, економічного, соціального і культурного залучення до будівництва глобалізованого світу; цее політична рішучість $i$ військова здатність відобразити нові загрози. Обидва циих компонента необхідні для надійного знищення тоталітарних мереж і антигуманістичних ідеологій.

Ключові слова: демократія, демократизачія, новий світовий порядок, міжнародний порядок, глобалізація, геополітика.

\section{ПРОБЛЕМАТИКА ДЕМОКРАТИЗАЦИИ В КОНТЕКСТЕ ФОРМИРОВАНИЯ НОВОГО МИРОВОГО ПОРЯДКА}

\section{И. В. Застава}

Проанализированы и обобщены теоретико-методологические подходы толкования и анализа мирового порядка. Рассмотрены ключевые вопросы влияния демократических прочессов на формирование нового мирового порядка. Определено, что суть нового мирового порядка состоит в построении единого, взаимосвязанного глобального мира, отказ от верховенства национальных государств и приоритете общечеловеческих интересов. Обосновано, что для решения проблем демократизации в условиях нового мирового порядка, необходимо реализовать следующие приниипь: это непременное ориентация западных демократий на собственные фундаментальные иенности: свободу, права человека, толерантность, демократию, верховенство права и социальную рыночную экономику; это признание необходимости и уважение международного порядка, основанного на общих цеенностях, на праве, согласии, сотрудничестве и участии в управлении, возможность политического, экономического, социального и культурного привлечения к строительству глобализирующегося мира; это политическая решимость $и$ военная способность отразить новые угрозы. Оба этих компонента необходимы для надежного уничтожения тоталитарных сетей и антигуманистических идеологий.

Ключевые слова: демократия, демократизация, новый мировой порядок, международный порядок, глобализащия, геополитика.

(C) I.В. Застава, 2020 


\section{PROBLEMS OF DEMOCRATIZATION IN THE CONTEXT OF FORMATION OF A NEW WORLD ORDER}

\section{Zastava}

Theoretical and methodological approaches to the interpretation and analysis of the world order are analyzed and generalized. The key issues of the influence of democratization processes on the formation of a new world order are considered. It is determined that the essence of the new world order is to build a single, interconnected and global world, the renunciation of the supremacy of nation-states and the priority of universal interests. It is substantiated that in order to solve the problems of democratization in the new world order, it is necessary to implement the following principles: it is the inevitable orientation of Western democracies to their own fundamental values: freedom, human rights, tolerance, democracy, rule of law and social market economy; it is the recognition of the need for and respect for an international order based on common values, law, harmony, cooperation and participation in governance, the possibility of political, economic, social and cultural involvement in the construction of a globalized world; it is political determination and military ability to repel new threats. Both of these components are necessary for the reliable destruction of totalitarian networks and anti-humanist ideologies.

It is noted that the spread of democratic institutions within the country was often accompanied by the collapse of democracy and the dominance of large powers at the interstate level, where the most important decisions had to be made on the world economy, proliferation and environmental protection. Liberal democracy, because it is the opposite of social democracy, is not responsible for meeting the needs of the most vulnerable societies. Adhering to the concept of world order and other normative-critical views, it can be noted that there is a possibility of devolution of the democratic mechanism of decision-making both at the regional, international level and at the level of self-government. The process of democratization is one of the elements in the effective construction of a new world order.

Key words: democracy, democratization, new world order, international order, globalization, geopolitics.

Постановка проблеми. Глобалізація відкриває перед людиною найширші можливості i, разом 3 тим, породжує проблеми, від вирішення яких залежить саме існування цивілізації. Серед таких проблем можна виділити такі, як забезпечення загального миру i безпеки, включаючи врегулювання неміжнародних конфліктів, нерозповсюдження зброї масового ураження, збереження навколишнього середовища, забезпечення функціонування світової економіки, зменшення розриву в рівні життя між багатими i бідними країнами, проблема народонаселення планети, включаючи охорону здоров’я, збереження загального спадщини людства та ін. Характерна особливість цих проблем полягає в тому, що вони можуть бути вирішені лише в результаті широкого співробітництва держав, зусиллями міжнародної спільноти в цілому. Для цього потрібне встановлення 
нового світового порядку, здатного істотно підвищити рівень керованості міжнародною системою в умовах надійного правопорядку (Shmitter, 2004, s. 126-144).

Демократизація в умовах глобалізації стала багатонаціональним процесом. Така «демократична» глобалізація в політичному плані повинна привести до перебудови міжнародної системи держав, до «нового світового порядку», в рамках якого буде забезпечено мирне і дружнє співіснування більш ніж 190 держав, численних регіонів і культур. Для цього потрібні не тільки сильні демократії, які спираються на міцний фундамент цінностей. Необхідні також сильні установи з багатостороннім участю (в першу чергу оновлена ООН), які були б здатні створити і підтримувати цей порядок відповідно до норм міжнародного права. Лише такий світовий порядок повинен бути здатний забезпечити мир і безпеку (Kissindzher, 2017, s. 124).

На шляху побудови нового світопорядку чимало перешкод. Поки не вивчені закономірності функціонування глобальної системи. Істотні перешкоди породжує політика держав, в першу чергу, найбільш розвинених, які прагнуть використовувати глобалізацію в своїх інтересах і не рахуються 3 інтересами інших держав і міжнародного співтовариства в цілому. Це переважно недемократичні країни або псевдодемократичні. Отже, процес демократизації є одним із елементів у ефективній побудові нового світового порядку.

Аналіз актуальних досліджень. Інтерпретація світового порядку знайшла відображення в головних наукових парадигмах про міжнародні відносини, що представлена у наукових працях Р. Арона, 3. Бжезинського, Г. Кіссінджера, С. Краснера, Г. Моргентау та К. Уолтца. Ліберальний напрямок у дослідженні світового порядку представлений у дослідженнях таких науковців, як Р. Кеохейн, Дж. Най, Дж. Розенау та ін. Серед вчених, які досліджували роль і місце транснаціональних еліт у процесі формування нового світового порядку слід виокремити - Д. Гутмена, Д. Рівера, Дж. Коулмена, К. Харві, Н. Хагера. 
Метою статті $\epsilon$ - виокремити і проаналізувати основні проблеми демократизації у контексті формування нового світового порядку.

Виклад основного матеріалу. Демократія, як стверджував У. Черчіль, далеко не найдосконаліший суспільний лад, але кращого поки людство не придумало. Наразі саме демократія - це єдина гарантія економічного i соціального розвитку нації і держави. Свобода особистості припускає економічну свободу, свободу торгівлі, свободу розвитку. Слово «демократія» означає «панування народу», а не простою більшістю. Поглинаючи в собі інститути громадянського суспільства, сучасна демократична держава іноді стає «тиранією більшості», що підзвітна електорату лише раз на кілька років. Повноваження, які демократія взяла на себе, разом із повноваженнями корпорацій, являють собою «новий світовий порядок» (Mosley, 2003).

«Новий світовий порядок» - це система уявлень про принципи устрою світового економічного, культурного та політичного життя, що проповідується теоретиками глобалізму. Їх суть полягає в побудові єдиного, взаємопов’язаного і глобального світу, відмову від верховенства національних держав i пріоритеті загальнолюдських інтересів. Саме на загальнолюдських інтересах і будуються демократизаційні процеси в сучасному світі (Malskij, 2011, s. 211).

Універсалістський підхід до нового світового порядку знайшов відображення в роботах Ф. Фукуями. Його концепція грунтується на тому, що історія має універсальну спрямованість і іï логічним завершенням стане перемога ліберальної демократії. Остання, на думку вченого, є найбільш раціональною з усіх створених людством систем, тому що саме вона здатна задовольнити людське прагнення до «визнання» та задоволення пріоритетних загальнолюдських інтересів: «Визнання - центральна проблема політики, тому що жага визнання є джерелом тиранії, імперіалізму і прагнення до панування». Неминучий перехід до лібералізму в світі обгрунтовується прагненням держав до збагачення, і найбільш придатна система реалізації цієї мети - ринкова економіка. Високий рівень добробуту, який 
забезпечувався б цією економічною моделлю, сприяє дозріванню країн для демократії (Fukuyama, 2015, s. 156).

Новий світовий порядок Г. Кіссінджера грунтується на циклічному поданні про історію міжнародному відношенні, в якому відбувається зміна дійових осіб, але закон балансу сил залишається вічною константою. Порядок існує, коли дотримується цей баланс, при його ігноруванні світ може поринути в хаос воєн і криз (Kissindzher, 2017, s. 78-80).

3. Бжезинський розуміє під новим світовим порядком строго ієрархічну структуру міжнародних відносин на чолі 3 демократичним тріумвіратом: США, СС і Японія. Спочатку 3. Бжезинський представляв світовий порядок таким чином - США, що стали після закінчення холодної війни єдиною наддержавою, здатні вибудувати архітектуру світової політики за своїм суб'єктивним баченням, в той час як Європі і Японії відводилася роль залежних супутників (Bzhezinskyi, 2018, s. 46-48).

Сучасний ліберальний світовий порядок був створений після завершення холодної війни на основі ліберального міжнародного порядку, що існував у другій половині XX ст. між США і їх союзниками з числа ринкових ліберальних демократій, з одного боку, і глобального балансу сил за участю п’яти ядерних держав, з іншого боку. Він поєднував у собі, таким чином, правила i звичаї країн, які виключили застосування сили при вирішенні спірних питань між собою, і цілком традиційну силову основу будь-якої більш-менш стійкої міжнародної рівноваги. Ці правила і звичаї включали в себе свободу торгівлі, відносну відкритість товариств один одному, інститути і вже згадуваний відмова від застосування військової сили. США були лідером серед країн Заходу, тому що володіли найбільшою військовою могутністю i могли забезпечувати умови, при яких інші отримували політичні та економічні блага (Voroneckij, 2019, s. 30-35).

США в тісній співпраці з Британією та іншими країнами - заснували ліберальний світовий порядок після Другої світової війни. Мета полягала в 
тому, щоб гарантувати - умови, що призвели до двох світових воєн, більше ніколи не виникнуть знову.

3 цією метою демократичні країни зайнялися створенням міжнародної системи, що була ліберальною та спиралася на принципи верховенства закону і поваги до суверенітету і територіальної цілісності країн. Права людини слід захищати. Всі ці принципи слід застосовувати до всього світу, при цьому участь в даній системі була відкрита для всіх країн. Були також створені інститути для сприяння миру (OOH), економічному розвитку (Світовий банк), торгівлі та інвестицій (Міжнародний валютний фонд) тощо (Kuts, 2011).

Все це і багато іншого спиралося на економічну і військову міць США, на мережу альянсів в Свропі і Азї, а також на ядерну зброю, що слугувало для стримування агресії. Тим самим, ліберальний світовий порядок спирався на ідеали демократичних країн. Bce це було спочатку не сприйняте пострадянськими країнами, 3 їх фундаментально іншими уявленнями 3 приводу ідеального порядку в Свропі i в усьому світі. Але поступово демократизаційні процеси набули більшого масштабу серед цих країн(Potiekhin, 2017, s. 5-9).

Ліберальний світовий порядок різко зміцнився після завершення Холодної війни і краху СРСР. Але наразі, його майбутнє - під питанням. Більш того, три його головні компоненти - лібералізм, універсалізм і захист порядку активно критикуються. Демократичні країни відчувають наслідки підйому популізму. У Європі набирають популярність політично крайні партії. Голосування Великобританії за вихід з $\mathrm{EC} \mathrm{засвідчило} \mathrm{факт} \mathrm{втрати}$ впливу елітою (Hantinhton, 2005, s. 574-582).

Стає все важче визначати демократизацію, як світовий процес. Відбувається поява різних регіональних порядків (або заворушень, що найбільш очевидно на Близькому Сході). Кожен 3 них має свої особливі характеристики. Спроби вибудувати глобальні системи провалюються, розширюється протекціонізм. Прийнято дуже мало законів, що регулюють 
використання кіберпростору, що дає можливість для розповсюдження антидемократичних ідей та дискредитуються демократичні цінності (Frolova, 2017, s. 34-42).

У той же час суперництво великих держав виходить на перший план у світовому процесі. Росія активно порушує базові норми міжнародних відносин, застосовує збройні сили для зміни кордонів в Європі. Північна Корея ігнорує потужний міжнародний консенсус в питанні про нерозповсюдження ядерної зброї. Втім, ослаблення ліберального демократичного світового порядку викликане зміною підходів в США. Під керівництвом президента Д. Трампа США вирішили не приєднуватися до Транс-Тихоокеанського партнерства і вийти з Паризького кліматичної угоди. США активно висувають наміри вийти з Північноамериканської угоди про вільну торгівлю (НАФТА) і Іранського ядерного угоди. У США було введено односторонньому порядку мита на сталь i алюміній, обгрунтовуючи це поясненням (питання національної безпеки), яким можуть скористатися i інші країни; тим самим, запущений процес, який загрожує світу торговельною війною. Підйом популізму частково став реакцією на стагнацію доходів і втрату робочих місць, що викликано, головним чином, впровадженням нових технологій, але часто пояснюється як наслідок зростання імпорту і припливу іммігрантів. Тим часом, глобальні інститути не змогли адаптуватися до нових балансів сили і до технологій (Voronetskyi, 2019, s. 30-35).

Науковці звернули увагу на те, що поширення демократичних інститутів всередині країни часто супроводжувало згортання демократії і домінування великих держав на міждержавному рівні, де повинні були прийматися найважливіші рішення з питань світової економіки, поширення зброї і захисту навколишнього середовища. Крім того, при збільшенні числа демократичних держав окремі науковці бачили в них структури, які не виконують свої функції і в більшості випадків не справляються 3 постійно 
наростаючим тиском транснаціональних сил і не здатні вирішити проблеми, що вимагають регулювання. Деякі науковці заявляють, що ліберальна демократія, оскільки вона протилежна соціальної демократії, не несе відповідальності за задоволення потреб найбільш уразливих суспільства. Відповідно, окремі науковці, які дотримуються концепції світового порядку і інших нормативно-критичних поглядів, вивчають можливість деволюції демократичного механізму ухвалення рішень як на регіональний, міжнародний рівень, так i на рівень самоврядування. Дійсно, тому що універсальні стандарти прав людини, до яких можуть апелювати індивіди поза державного ладу, були сформульовані на міжнародному рівні транснаціональними громадськими рухами i неурядовими організаціями, деякі побачили в цьому початок зародження глобального суспільства. Отже, ліберальний демократичний світовий порядок не може вижити сам по собі, тому що у інших країн немає або інтересу, або коштів, для його збереження. В результаті може з'явитися світ, в якому буде менше свободи (Hantinhton, 2003).

Висновки і перспективи подальших досліджень. Таким чином, для вирішення проблем демократизації в умовах нового світового порядку, слід щоб визначені принципи були максимально реалізовані.

Перший принцип - це неодмінна орієнтація західних демократій на власні фундаментальні цінності: свободу, права людини, толерантність, демократію, верховенство права і соціальну ринкову економіку.

Другий принцип - це визнання необхідності і повагу міжнародного порядку, заснованого на спільних цінностях, на праві, злагоді, співробітництво та участі в управлінні. Це повинен бути не порядок примусу i несвободи, а порядок, що надає максимальній кількості держав і їхнім громадянам можливість політичного, економічного, соціального і культурного залучення до будівництва глобалізованого світу. 
I третій принцип - це політична рішучість і військова здатність відобразити нові загрози. Обидва цих компонента необхідні для надійного знищення тоталітарних мереж і антигуманістичних ідеологій.

Вони мають вирішальне значення для того, щоб рішуче i успішно відвернути загрози XXI століття. Саме поєднання цих трьох принципів, що визначають ефективний мультилатералізм (багатосторонні відносини), має стати базою для західних демократій. Таких напрямків слід дотримуватися, вносячи спільний внесок в будівництво мирного, справедливого, демократичного світового порядку.

\section{ЛІТЕРАТУРА}

1. Бжезінський, 3. 2018. Велика шахівнищя. Київ.

2. Воронецький, О. 2019. Свропа та США у становленні світового порядку після закінчення «холодної війни». Травневі cmydiï, 4, c. 30-35.

3. Гантінгтон, С. Ф., $2005 . \quad$ Три хвилі демократизації. В: О. Проценко, ред. Демократія : антологія. Київ: Смолоскип. с. 574-582.

4. Дорош, Л. О. 2015. Основи теорії міжнародних відносин: навчальний посібник. Львів.

5. Кіссінджер, Г., 2017. Світовий порядок. Роздуми про характер начій в історичному контексті. Київ.

6. Куц, Г. М., 2011.2 Ліберальні трансформачї політичного простору: монографія. Харків.

7. Мальський, М. 3., $2011 . \quad$ Теорія міжнародних відносин. Київ.

8. Потехін, О., 2017. США, НАТО і загрози сучасному світовому порядку. Зовнішні справи, 11, с .5-9.

9. Фролова, О., 2017. Глобалізаційні процеси в інформаційній сфері та їх вплив на новий світовий порядок. Міжнародні відносини. Політичні науки, 17 с. 34-42.

10. Фукуяма, Ф., 2015. Конеи истории и последний человек. Москва.

11. Хантингтон, С., 2003. Третья волна: Демократизащия в конще XX века. Москва: РОССПЭН.

12. Шміттер, Ф. К., 2004. Небезпеки і дилеми демократії. Переклад 3 англійської В: Л. Даймонд, М. Ф. Платнер, ред. Глобальне відродження демократії.

\section{REFERENCES}

1. Bzhezinskyi, Z. 2018. Velyka shakhivnytsia. Kyiv.

2. Voronetskyi, O. 2019. Yevropa ta SShA u stanovlenni svitovoho poriadku pislia zakinchennia «kholodnoi viiny». Travnevi studii, 4, s. 30-35.

3. Hantinhton, S. F., 2005. Try khvyli demokratyzatsii. V: O. Protsenko, red. Demokratiia : antolohiia. Kyiv: Smoloskyp. s. 574-582.

4. Dorosh, L. O. 2015. Osnovy teorii mizhnarodnykh vidnosyn: navchalnyi posibnyk. Lviv.

5. Kissindzher, H., 2017. Svitovyi poriadok. Rozdumy pro kharakter natsii $v$ istorychnomu konteksti. Kyiv.

6. Kuts, H. M., 2011. Liberalni transformatsii politychnoho prostoru: monohrafiia. Kharkiv.

7. Malskyi, M. Z., 2011. Teoriia mizhnarodnykh vidnosyn. Kyiv.

8. Potiekhin, O., 2017. SShA, NATO i zahrozy suchasnomu svitovomu poriadku. Zovnishni spravy, 11, s .5-9.

9. Frolova, O., 2017. Hlobalizatsiini protsesy v informatsiinii sferi ta yikh vplyv na novyi svitovyi poriadok. Mizhnarodni vidnosyny. Politychni nauky, 17 s. 34-42.

10. Fukuyama, F., 2015. Konec istorii i poslednij chelovek. Moskva.

11. Hantington, S., 2003. Tretya volna: Demokratizaciya v konce XX veka. Moskva: ROSSPEN.

12. Shmitter, F. K., 2004. Nebezpeky i dylemy demokratii. Pereklad $\mathrm{z}$ anhliiskoi V: L. Daimond, M. F. Platner, red. Hlobalne vidrodzhennia demokratii. Lviv: Akhill. 
Львів: Ахілл. с. 126-144.

13. Mosley, I. 2003. Democracy, fascism and the new world order. NY. s. $126-144$.

13. Mosley, I. 2003. Democracy, fascism and the new world order. NY.

\section{Інформація про автора}

Застава Ірина Валентинівна - кандидат політичних наук, доцент кафедри міжнародних відносин, міжнародної інформації та безпеки, факультету міжнародних економічних відносин та туристичного бізнесу Харківського національного університету імені B.H. Каразіна; e-mail: i.v.zastava@karazin.ua; ORCID: http://orcid.org/0000-0002-7604-8823.

Стаття надійшла до редакції: 27.11.2019 р. $\quad$ Прийнята до друку: 16.12.2019 p. 